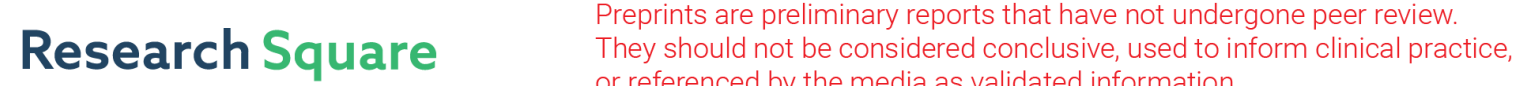 or referenced by the media as validated information. \\ Non-Oil Revenue and Economic Growth on major net oil exporters? Evidence from Saudi Arabia
}

Raja Almarzoqi

MEP

Assil EL MAHMAH ( $\nabla$ assil.elmahmah@yahoo.fr)

NBK

Research

Keywords: Economic reforms, Non-oil revenue, Negative side effects, Fiscal policy, Economic Growth.

Posted Date: December 23rd, 2020

DOI: https://doi.org/10.21203/rs.3.rs-132808/v1

License: (9) This work is licensed under a Creative Commons Attribution 4.0 International License. Read Full License 


\title{
Non-Oil Revenue and Economic Growth on major net oil exporters? Evidence from Saudi Arabia
}

\author{
Raja Almarzoqi and Assil El Mahmah
}

\begin{abstract}
This research paper attempts to assess the impact of the economic reforms on the fiscal policy adopted recently by the Kingdom of Saudi Arabia (KSA), which aim to increase non-oil revenues and diversify the government income away from oil. To this end, a small-scale macroeconomic model comprising several econometric equations has been estimated using the OLS method over the period 1990-2018, in order to take into account numerous channels through which macroeconomic drivers can affect economic growth for the KSA's economy.

The results show that, on one hand, increasing non-oil revenue has led to a surge in government spending, which contributed, to a lesser extent, to boost total consumption and private investment. However, this continued rise in revenue, through cutting subsidies, implementing VAT and introducing fees and taxes, has on the other hand put more pressure on the private sector and disposable income starting to weaken the investment and consumption. These measures eventually will increase the cost of living as well as the cost of labor, which contradicts the vision 2030 goals to increase the non-oil export. Our finding revealed also that enhancing non-oil revenue would probably not offset its negative side effects, if the government is still aggressive with these types of policy reforms.
\end{abstract}

JEL codes: E62, O40, O53, Q48

Keywords: Economic reforms, Non-oil revenue, Negative side effects, Fiscal policy, Economic Growth. 


\section{Declarations}

\section{Availability of data and materials}

The variables used and analysed during the current study are available in the following Datasets/websites:

- General Authority for Statistics: https://www.stats.gov.sa/en/823

- Saudi Arabian Monetary Authority (Saudi Central Bank): https://www.sama.gov.sa/enUS/EconomicReports/Pages/YearlyStatistics.aspx

- OPEC: https://www.opec.org/opec web/en/data graphs/335.htm

- IMF Database: https://www.imf.org/en/Publications/WEO/weo-database/2020/October

- Bloomberg.

\section{Competing interests}

We (both authors) declare that we have no competing interests.

\section{Funding}

We (both authors) do not get any kind of funding for this research.

\section{Authors' contributions}

Dr. Raja Almarzoqi contributed mainly to the conception of the paper, the design of the adopted approach, and the interpretation of the results, while Assil El Mahmah is responsible for the data collection and the econometric modeling using Eviews as well as the estimating of the results. Finally, both authors have drafted and revised the final paper together, then added some policy Recommendations.

\section{Acknowledgments}

Earlier version of this paper have been presented at the Center for International Development at Harvard University. We would like to thank the reviewers for their valuable comments and effort to improve this paper. 


\section{Introduction}

Over the past decade, the major net oil exporters have enjoyed large external and fiscal surpluses as well as rapid economic expansion on the back of oil price stability around $\$ 105$ per barrel during the four-year period. But with oil prices plunging since the second half of 2014, external and fiscal surpluses have turned into deficits and growth has slowed, raising concerns about fiscal sustainability and its implications for macroeconomic stability.

Saudi Arabia is no exception. The Kingdom faced a number of economic challenges. Its economic growth has moderated amid low oil prices, due to the adopted fiscal consolidation and the continued cut of oil production as well as the introduction of taxes and fees. Therefore, in order to adjust to low oil prices, KSA has undertaken significant fiscal reforms since 2015, such as subsidy cuts and lower public spending, as well as mobilization of additional non-oil revenues. Excise taxes on tobacco and energy drinks were introduced in July 2017, while a value-added tax (VAT) at a rate of 5\% was implemented since January 2018. Moreover, fees on foreign workers were increased in January 2018 and new fees on dependents were introduced starting July 2017. These reforms increased non-oil revenues from $4.8 \%$ of GDP (8.2\% of non-oil GDP) in 2015 to $8.2 \%$ of GDP $(12.4 \%$ of non-oil GDP) in 2018, making non-oil tax revenue collections in Saudi Arabia higher than in other GCC countries.

However, the measures that aimed to increase non-oil revenue appears also to have a negative impact on consumption and investment (figure 1). Besides increasing non-oil revenues, the government has also encouraged the hiring of more Saudi citizens by introducing fees for foreigners, which started leaving the kingdom by thousands every month, without being replaced. In fact, Saudi Arabia had previously hoped that the job vacancies left by expatriates would be filled by Saudi nationals but, it is quickly becoming clear that locals are not filling the gaps, as most of the expats who left either were unskilled working in construction/service sectors or worked in the informal sector, while more than two-thirds of Saudis seeking job have a university degree. This has put more pressure on the labor market without solving the original problem. with an increase in hiring costs and higher wages, causing rising a little bit the inflation, and consequently weaken the competitiveness of the private sector. In addition, the exit of foreigners has reduced real private consumption and affected negatively the housing market, with the rent decreased since late 2017.

To mitigate the impact of these reforms, the authorities decided to use cash payments to Saudi nationals through the "Citizens Accounts" for low and middle-income households, as well as additional cost of living allowances for government workers, pensioners, students, and those on social security. These were originally introduced in 2018 for one year but have been extended to end-2020. Thus, Government spending on these payments and allowances increase fiscal expenditures, reducing the net fiscal impact of these reforms and weakening KSA fiscal position. 


\section{Figure 1: Mixed effect of increasing non-oil revenue}

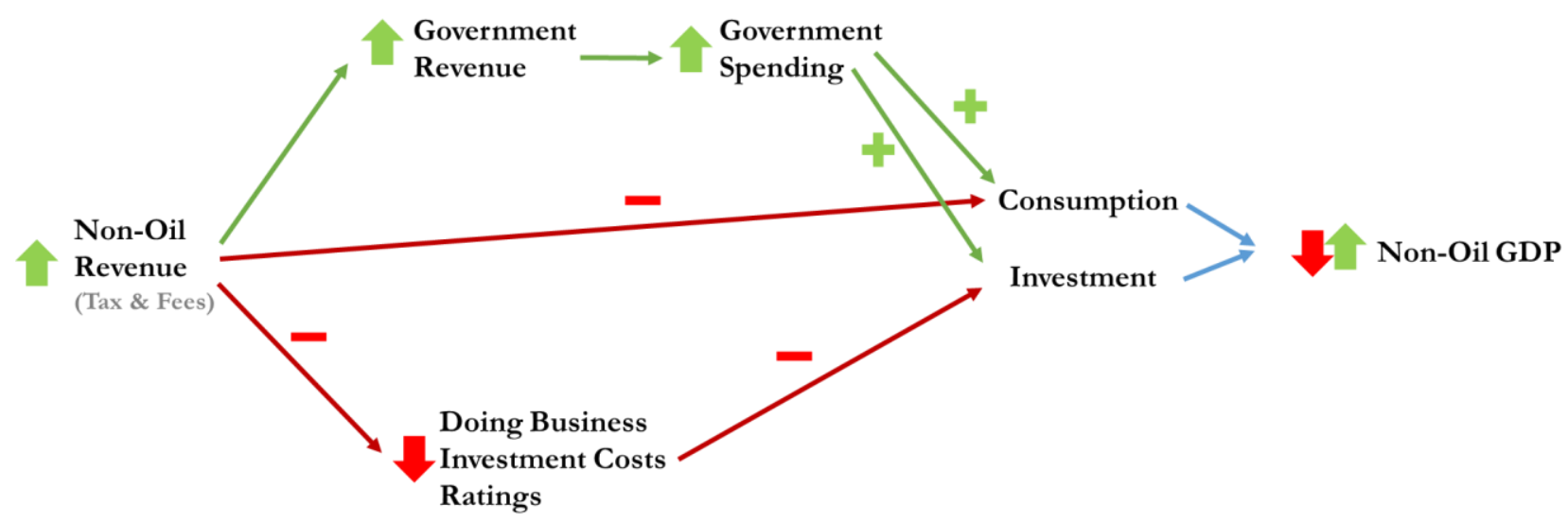

To understand the net impact of non-oil revenue in the recent economic reforms on Saudi Arabia's economy, a small-scale macroeconomic model comprising several econometric equations has been estimated using the OLS method over the period 1990-2018. Our adopted model consists of building several simultaneous econometric equations, to take into consideration all different channels through which taxes and fees can affect the KSA economy. This allows us to quantify the direct and indirect effects of an increase in non-oil revenue not only on GDP, but also on consumption, credit, and investments, as well as to simulate alternative scenarios about the pace of fiscal reforms going forward and to analyze its implications.

The rest of the paper is organized as follows. The next section is a literature review discussing global evidence about the impact of taxation on the economy. The methodology explained in section 3 where data description and modeling discussed in detail. Section 4 presents the empirical results of the model as well as simulates alternative scenarios about the pace of fiscal reforms going forward and its implications. The last section concludes with a discussion of policy recommendations and key issues.

\section{Literature Review}

Despite a considerable amount of empirical research on the relationship between fiscal policies and economic performance, the fundamental question of whether or not increasing non-oil revenue (mainly through taxes and fees), especially in resource-rich countries, can affect the pace of economic growth, is widely debated. The empirical literature showed that this relationship is poorly understood. On the one hand, implementing taxes increase government revenue and lead to higher expenditures that could boost economic growth, if they are spent in productive ways. On the other hand, higher taxes can weaken the private sector's contribution to the economy and affect negatively private domestic consumption, which could undermine the overall economic performance. 


\subsection{Global evidence}

Mostly based on cross-section studies, results and evidence differ by country/region, the analytical approach employed, as well as by structures of the tax system. Some of these studies suggest that taxation has a negative and significant impact on GDP growth; others have shown a positive relationship between the two variables, while others were inconclusive.

Haq-Padda and Akram (2009) examined whether tax policies conducted by Pakistan, India and Sri Lanka have a transitory or permanent effect on their economic growth. The study finds a transitory and negative effect of the tax rate on the growth only for the short-term, but has no effect on the long-term, given that the tax rates in all these countries are low as compared to developed countries.

Widmalm (2001) showed, using pooled cross-sectional data from 23 OECD countries between 1965 and 1990, that there exists a negative relationship between personal income tax, measured by average income tax, and economic growth, while corporate income tax does not correlate with growth at all.

However, Ramot and Ichihashi (2012) used panel data from 65 countries over the period 1970-2006 to study the effects of tax structure on economic growth and income inequality. They found that company income tax rates have a negative impact on both economic growth and income inequality, while increasing the personal income tax rate does not significantly affect the two variables. These results were confirmed by Lee and Gordon (2005), using cross-country data from 70 countries data over the period 1970-1997.

Padovano and Galli (2001) used econometric estimates of effective marginal income tax rates for 23 OECD countries from 1951 to 1990. They argued that average tax rates lead to several biases and concluded that taxation has no impact on growth because of the possibility of a high correlation with average fiscal spending.

\subsection{Empirical literature on net oil-exporting countries}

Despite the importance of the oil sector and its revenues in many net oil-exporting countries, fewer studies investigated how tax policies in such countries affect economic growth. In fact, evaluating the impact of increasing non-oil revenue on economic growth has received less attention and has been somewhat neglected, given the abundance of oil revenue and the absence of clear taxation systems in these countries. However, the recent decline in oil prices and the acceleration of economic diversification had revived the interest of academia, central banks, and governments in understanding the relationship between non-oil revenue (especially tax revenue) and economic growth in oil-rich countries.

Kaghazian et al. (2013) studied the relationship between tax effort and oil revenues in five oilexporting countries including Algeria, Bahrain, Iran, Kuwait, and Qatar, using the panel-data model for the period 2000-2009. The results support a negative relationship between tax-to-GDP ratio and 
oil incomes (tax effort decreases, as oil incomes increase). In addition, there is a positive relationship between economic growth and tax effort, given that the tax to GDP ratio is low in these countries compared to international standards. They recommended that tax policies should take into consideration the balance between revenue collected and economic growth.

Odhiambo O. and Olushola O. (2018) examined the relationship between taxation and economic growth in a resource-rich country, selecting Nigeria as a case study, with a focus on the tax structure. Using Ordinary least square (OLS) estimation techniques over the period 1986-2015, they explored the linkages between the availability of higher resource revenue and lower taxation effort of other revenue categories and the effects of these on growth. Their empirical results revealed that taxation has a significant negative impact on real GDP growth rates. However, the proportion of tax contribution to the growth rate falls short of the optimal level in terms of the volume of economic activities and the value of total output. They conclude that the objective of the implementation of any tax structure should be to attain maximum revenue with minimum distortions of economic growth.

Srithongrung and Sanchez (2015) investigated the effects of taxes and public investment on economic growth in Mexico, using data from 32 states during the period of 1993-2011. The empirical results indicate that taxes have a negative effect on growth and the effect can be seen in both transitory and permanent manners. They concluded that an appropriate fiscal policy (equilibrium between public investment and taxes) is required to boost economic growth in this country.

Regarding Saudi Arabia, the International Monetary Fund (IMF) just published recently (September 2019) a Selected Issues Paper on Saudi Arabia to assess the macroeconomic effects of the non-oil revenues reforms. Their findings revealed that real private consumption and real investment are negatively affected by the introduction of the VAT and the expat levy, while the reforms had a modest impact on the inflation, which increased only temporary with the introduction of the VAT.

Our paper differs from the above-mentioned literature as follows. First, this study assesses the impact of increasing non-oil revenue on the economic activity of oil-rich countries, using Saudi Arabia as a case study. Second, most of the existing literature focuses on the direct effect of taxes on economic growth, neglecting other transmission channels. For that reason, unlike other approaches in previous studies, the model adopted consists of building several simultaneous econometric equations, in order to take into consideration all different channels through which taxes and fees can affect the KSA economy. Third, this model is solved simultaneously, allowing for interactions among the variables, instead of solving it sequentially by blocks. Therefore, we can quantify the direct and indirect effects of an increase in non-oil revenue not only on GDP, but also on consumption, credit, and investments. Finally, the model allows us to simulate alternative scenarios about the pace of fiscal reforms going forward and to analyze its implications, in the context of continued oil price volatility. 


\section{Methodology}

To understand the impact of non-oil revenue in the recent economic reforms on Saudi Arabia's economy, a small-scale macroeconomic model comprising several econometric equations has been estimated using the OLS method over the period 1990-2018. The choice of what type of model to develop is based on the KSA's economy characteristics, data limitation, and the intended objectives. As the Kingdom depends highly on oil revenues to support its non-oil economic growth, one of the design criteria in the proposed macro model is to focus on the non-oil GDP growth, which is a better indicator of KSA economic activity. Indeed, given that the oil GDP depends mainly on the oil production and its price fluctuations in the international market, changes in overall GDP is affected by this volatility, which could be a very misleading measure of growth for the KSA economy. In addition, this model should take into consideration all different channels through which main macroeconomic drivers can affect the KSA economic activity, in order to anticipate the implications of different shocks on the consumption, private investment, government spending, and domestic credit. Another important criterion is to analyze the impact of oil price fluctuations on the main drivers of economic activity. Finally, the model should be useful for evaluating alternative scenarios about fiscal policy, namely non-oil revenue and government spending that is necessary to achieve the KSA's Vision 2030.

\subsection{Data Description}

For estimation purposes, we use annual data for the period 1990-2018, since the selected variables are not all available on a quarterly basis. Nevertheless, this study period is relatively long compared to those considered in other studies, especially for the GCC. Thereby, the main data sources for our model are the General Authority for Statistics and the Saudi Arabian Monetary Authority (SAMA). In addition, the oil production data was abstracted from OPEC, while the federal funds rate (FFR) and the Brent crude oil price are sourced from Bloomberg (Appendix 1).

It is noteworthy to mention that non-oil revenue is an important variable in our model and considered new in the literature. It was rarely used for KSA (and most of the rich oil economies), given the dominance of oil revenue in the budget structure of the Saudi economy. But given the current reforms, we expect that this variable is becoming significant and should be integrated into all macroeconomic models for KSA.

According to the literature, a number of other fundamental variables may be relevant for this study. For example, the unemployment rate, wages, household incomes, sovereign wealth fund assets could also be considered as the key factors in our adopted model, but they are not reliable or not available for our purposes. Fortunately, ignoring these variables might not be problematic, since our adopted model describes well the important channels through which main macroeconomic drivers can affect the KSA economic activity. 
In the econometric analysis, all the series are expressed in real terms. Those that were originally available as nominal series were deflated by the CPI index. Moreover, all variables are expressed in the growth rate for estimation purposes, except for the FFR. Finally, stationarity of the variables was tested using the Augmented Dickey-Fuller (ADF) test, which indicates that all the series selected in this model are stationary.

\subsection{Model Specification}

The model consists of building 10 economic relations, which are modeled by econometric equations and estimated using ordinary least squares (OLS). This paper focused only on five main channels. It comprises (1) non-oil GDP equation, (2) Government Spending equation, (3) Consumption equation, (4) Private investment and (5) credit equation. The structure of each equation is based on macroeconomic theory, but adapted to the Saudi Arabia specificities and to data availability. It also takes into consideration the statistical significance and the forecasting accuracy of the adopted model. Figure 2 outlines the overall structure and interrelations of our empirical model. It gives a detailed description of the economic relationships between the exogenous and the endogenous variables of the model.

Figure 2: Economic Relationships of the adopted Model

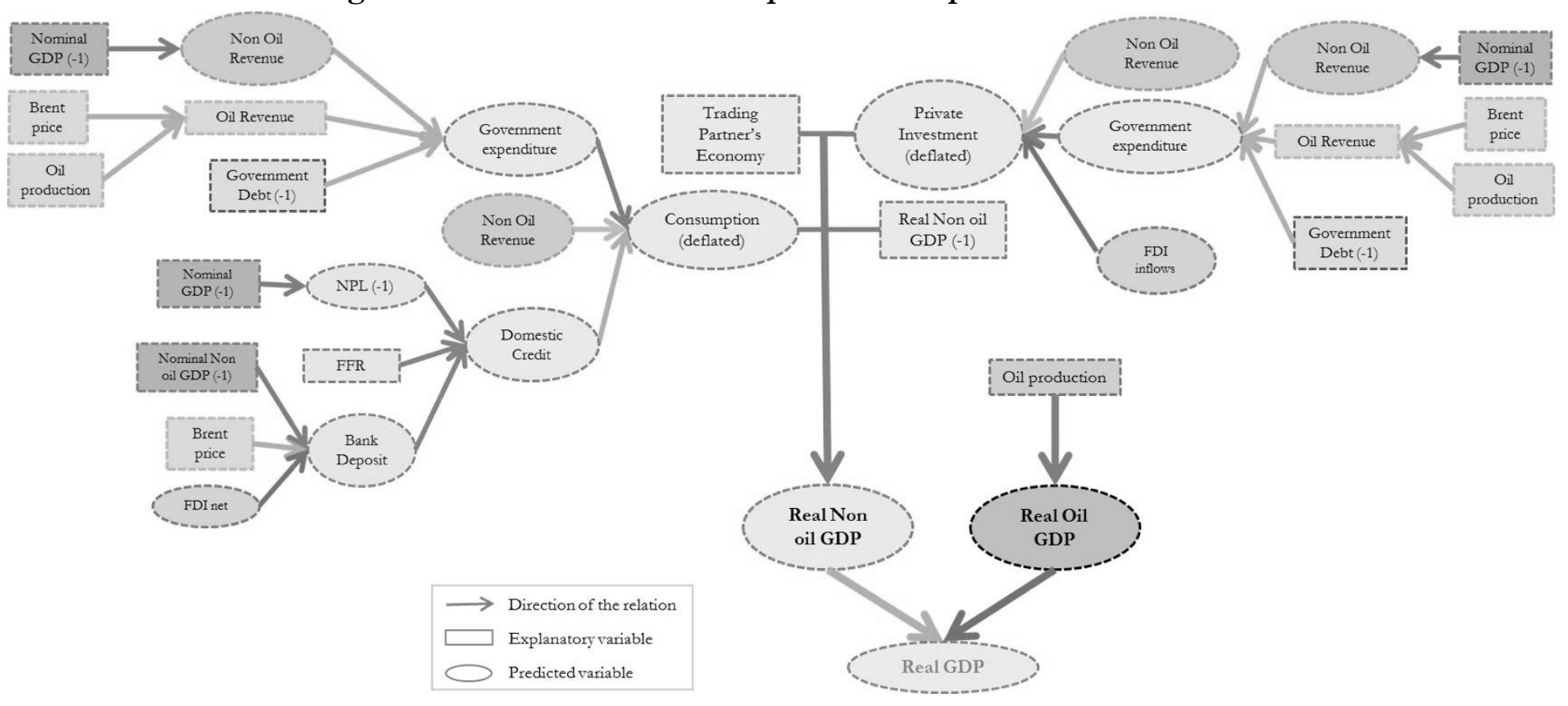


According to the relationships described in Figure 2, each equation reflects the main drivers of each block and is expressed as a function of exogenous variables as well as some endogenous variables from the previous equations. Furthermore, in order to take into consideration some lagged effects of the independent variables in the equations, we added a statistically significant number of lags, in line with the existing literature. As a result, the main equations of our adopted models are described as follows.

\subsubsection{Non-Oil GDP equation}

Our first and main equation in our model includes four explanatory variables that affect KSA's non-

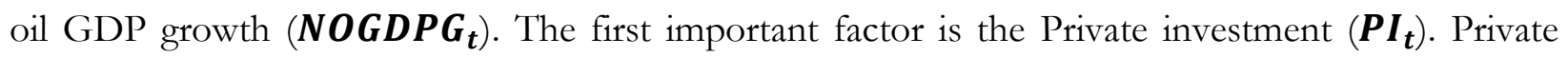
investment is an important part of an economy and a good indicator of non-oil growth. It is argued that private investment is a central strategy of achieving economic growth through its ability to stimulate additional economic activities by creating jobs and expanding the capacity for producing goods and services.

The second explanatory variable is Consumption $\left(\boldsymbol{C o n s}_{\boldsymbol{t}}\right)$. It is a key driver of economic growth, making it a vital component of GDP. Third, since the KSA is an open market with many activities, the national GDP depends also on the economic activity of its economic partners, which is measured by the Economic Partners Index ${ }^{1}\left(\boldsymbol{E P} \boldsymbol{I}_{\boldsymbol{t}}\right)$. This occurs through at least two channels: external non-oil demand and foreign investments. Higher EPI implies higher KSA's exports and higher inward FDI flows, which increases consequently non-oil GDP growth.

For the fourth variable, the domestic GDP depends also on the previous GDP, which can be captured by including a lag of GDP ( $\left.\boldsymbol{G D} \boldsymbol{P}_{\boldsymbol{t}-\mathbf{1}}\right)$ in the regression. This lag captures persistence and any missing effects that are not accounted for in the model, such as habits in consumption, expectations, or other factors.

Finally, in order to avoid the endogeneity and the autocorrelation, we did not include in this equation the FDI as a driver of the non-oil economy sector, despite its importance, as it is highly correlated with variables in the model. In fact, as mentioned in the previous section, the EPI is highly correlated with the foreign investment flows and reflects well its fluctuations. Thus, the regression specification is given below:

$$
N O G D P G_{t}=\delta_{0}+\delta_{1} P I_{t}+\delta_{2} \text { Cons }_{t}+\delta_{3} E P I_{t}+\delta_{4} G D P_{t-1}+\xi_{t}
$$

\footnotetext{
${ }^{1}$ The Economic Partners Index (EPI) is calculated as a weighted average of the real GDP of ten major economic partners (India, UAE, Bahrain, Oman, Switzerland, Turkey, UK, Kuwait, USA and China). These countries are in the Top10 of the KSA export destination. For estimation purposes and given the data limitation, the weights are obtained as normalized share of these countries in KSA's exports in the period 2015-2017.
} 
Where $\boldsymbol{\delta}_{\boldsymbol{i}}$ is the coefficient and $\boldsymbol{\xi}_{\boldsymbol{t}}$ is the error term.

\subsubsection{Government spending equation}

According to the literature and the experience in many developed and developing countries, most of the econometric models consider Government expenditure as an exogenous variable, given that it is a discretionary Government decision and is usually tied to the projections of the budget. However, in the Oil exporting countries, there is a high correlation with the oil price fluctuation, a major source of revenues, and the fiscal policy. An increase in spending is usually financed through collecting more oil revenues in a high oil price cycle. Thus, changes in oil revenues will have implications either on expenditures and/or on the budget balance. For the KSA, Government Spending growth $\left(\boldsymbol{G} \boldsymbol{S}_{\boldsymbol{t}}\right)$ is mainly explained by oil revenues $\left(\boldsymbol{O} \boldsymbol{R}_{\boldsymbol{t}}\right)$, which depend on Oil Production $\left(\boldsymbol{O P}_{\boldsymbol{t}}\right)$ and Brent Price $\left(\boldsymbol{B P}_{\boldsymbol{t}}\right)$. Moreover, through its Vision 2030, KSA implemented several economic reforms to raise nonoil revenue $\left(\boldsymbol{N O} \boldsymbol{R}_{\boldsymbol{t}}\right)$ away from Oil sector, which could in theory boost government spending even in the low oil price cycles. Finally, in the case of a budget deficit, the government could look for other sources of financing, such as issuing more debt or using its financial buffers, drawing down savings in Sovereign Wealth Funds (SWFs), which could impact its credit rating. In this equation, we focused on debt $\left(\boldsymbol{D} \boldsymbol{e b t} \boldsymbol{t}_{\boldsymbol{t}}\right)$ and $\left(\boldsymbol{N O \boldsymbol { R }} \boldsymbol{t}_{\boldsymbol{t}}\right.$, given the absence of any reliable data on the rules governing the use of the KSA's financial buffers. Therefore, the model equation is shown below:

$$
G S_{t}=\eta_{0}+\eta_{1} O R_{t}+\eta_{2} D e b t_{t}+\eta_{3} N O R+\Omega_{t}
$$

Where $\boldsymbol{\eta}_{\boldsymbol{i}}$ is the coefficient, $\Omega_{\boldsymbol{t}}$ is the error term and $\boldsymbol{O} \boldsymbol{R}_{\boldsymbol{t}}=\boldsymbol{B} \boldsymbol{P}_{\boldsymbol{t}} * \boldsymbol{O} \boldsymbol{P}_{\boldsymbol{t}}$ represents a proxy of oil revenue.

\subsubsection{Consumption equation}

According to the existing literature, especially in oil-exporting countries, the main macroeconomic determinants of consumption $\left(\boldsymbol{C o n s}_{\boldsymbol{t}}\right)$ are Government Spending $\left(\boldsymbol{G} \boldsymbol{S}_{\boldsymbol{t}}\right)$ and Domestic Credit $\left(\boldsymbol{D} \boldsymbol{C}_{\boldsymbol{t}}\right)$. In addition, KSA has sought to boost government revenue by implementing VAT and reducing subsidies, as well as introducing expatriate dependent fees. These measures have increased the cost of doing business by increasing the cost of labor in two ways. First, through an increase in the cost of living that pushes the average wage higher. Second, directly as employers need to pay these expat levy. This could be reflected by a contraction in consumption. For this reason, the non-oil revenue (NOR $)$ is included in this equation to take into consideration this potential negative impact. Hence, the Consumption equation is as follows:

$$
\operatorname{Cons}_{t}=\gamma_{0}+\gamma_{1} G S_{t}+\gamma_{2} D C_{t}+\gamma_{3} N O R+\vartheta_{t}
$$


Where $\boldsymbol{\gamma}_{\boldsymbol{i}}$ is the coefficient and $\boldsymbol{\vartheta}_{\boldsymbol{t}}$ is the error term.

\subsubsection{Private Investment equation}

In general, Private Investment $\left(\boldsymbol{P} \boldsymbol{I}_{\boldsymbol{t}}\right)$ in oil-exporting countries, which lack fiscal rules, has traditionally been dependent largely on government spending $\left(\boldsymbol{G} \boldsymbol{S}_{\boldsymbol{t}}\right)$ since the government owns the oil sector. In Saudi Arabia, the oil sector consists of more than 30\% of the GDP and redistributes its revenue through its budget. Hence, the leading sector in such a case would be the oil sector and its owner, which most of the time is the government. Saudi Arabia is no exception. However, the continued increase of taxes and fees on firms and expatriate workers to raise KSA's government revenue and enable the government to continue its spending $\left(\boldsymbol{G} \boldsymbol{S}_{\boldsymbol{t}}\right)$, started to raise the cost of production and put more pressure on the private sector. This could have a negative impact on the private investment and consequently on the non-oil economy. Another factor that could affect the private sector is the foreign direct investment inward flows $\left(\boldsymbol{F} \boldsymbol{D I} \boldsymbol{I}_{\boldsymbol{t}}\right)$. In fact, an improvement of foreign inflow would not only boost domestic investment, but also reflect a healthy economy and an enhancement in doing business in KSA. Thus, the regression specification is as follows:

$$
P I_{t}=\alpha_{0}+\alpha_{1} G S_{t}+\alpha_{2} N O R_{t}+F D I_{t}+\varepsilon_{t}
$$

Where $\boldsymbol{\alpha}_{\boldsymbol{i}}$ is the coefficient and $\boldsymbol{\varepsilon}_{\boldsymbol{t}}$ is the error term.

\subsubsection{Domestic Credit equation}

Although researchers used multiple different approaches for the major economies, modeling credit fluctuations in the KSA was difficult, because of the absence of reliable time series data for the variables that are used commonly in the literature. Thus, after several statistical tests, the adopted key factors in explaining Domestic Credit $\left(\boldsymbol{D} \boldsymbol{C}_{\boldsymbol{t}}\right)$ in the KSA are Non-Performing Loans $\left(\boldsymbol{N P} \boldsymbol{L}_{\boldsymbol{t}}\right)$ and bank Deposits $\left(\boldsymbol{B D}_{\boldsymbol{t}}\right)$. Moreover, given that the KSA currency is pegged to the US dollar and the Saudi Arabian Monetary Authority follows the US Federal Reserve's monetary policy, the federal funds rate $\left(\boldsymbol{F F} \boldsymbol{R}_{\boldsymbol{t}}\right)$ was also included in the equation. In fact, an increase (decrease) of the US interest rate should be reflected by an increase (decrease) of the KSA's interest rate, which should affect the national credit market. For that reason, the final equation is as follows:

$$
D C_{t}=\beta_{0}+\beta_{1} N P L_{t-1}+\beta_{2} B D_{t}+\beta_{3} F F R_{t}+\mu_{t}
$$

Where $\boldsymbol{\beta}_{\boldsymbol{i}}$ is the coefficient and $\boldsymbol{\mu}_{\boldsymbol{t}}$ is the error term.

\section{Empirical Results}

After evaluating the reliability and the predictive accuracy of the model for the period 1990-2015 (Appendix 2), we estimated the model over the period 1990-2018, and then we calculated the baseline 
forecasts for the period 2019-2021, using assumptions regarding future fluctuations of the exogenous variables (Appendix 2). Once done, we analyzed the dynamic response of the key variables to non-oil revenue fluctuations, in order to evaluate the impact of the adopted economic reforms on the consumption and private investments, as well as non-oil economic growth.

\subsection{Model estimation results}

This model is solved simultaneously, in order to allow more interactions among the variables. Table 1 showed the estimation results for the five selected equations of the adopted model during the period 1990-2018, which is expressed by its main explanatory variables. According to the statistical tests, the results are generally statistically significant and in line with the economic theory. All coefficients are statistically significant and with the expected signs. Therefore, the five equations describe well the important channels through which main macroeconomic drivers can affect the KSA economic activity over the period 1990-2018. 
Table 1: Estimation results of the adopted Model during the period 1990-2018

\begin{tabular}{|c|c|c|c|c|c|}
\hline Variables & $\begin{array}{l}\text { Equation (1) } \\
\text { NOGDP }\end{array}$ & $\begin{array}{l}\text { Equation (2) } \\
\text { Gov. spending }\end{array}$ & $\begin{array}{l}\text { Equation (3) } \\
\text { Consumption }\end{array}$ & $\begin{array}{c}\text { Equation (4) } \\
\text { Private } \\
\text { Investment } \\
\end{array}$ & $\begin{array}{c}\text { Equation (5) } \\
\text { Domestic } \\
\text { Credit } \\
\end{array}$ \\
\hline$N O G D P G_{t-1}$ & $0.33 *$ & & & & \\
\hline Cons $_{t}$ & $0.15^{*}$ & & & & \\
\hline$P I_{t}$ & $0.06^{*}$ & & & & \\
\hline$E P I_{t}$ & $0.31 *$ & & & & \\
\hline$O R_{t}$ & & $0.26^{*}$ & & & \\
\hline$N O R_{t}$ & & $0.11^{*}$ & $-0.17 * *$ & $-0.19 * *$ & \\
\hline$D e b t_{t-1}$ & & $-0.37 * *$ & & & \\
\hline$G S_{t}$ & & & $0.25^{*}$ & $0.65^{*}$ & \\
\hline$D C_{t}$ & & & $0.51^{*}$ & & \\
\hline$F D I_{t}$ & & & & $0.11 *$ & \\
\hline$B D_{t}$ & & & & & $1.15^{*}$ \\
\hline$N P L_{t-1}$ & & & & & $-0.11 * *$ \\
\hline$F F R_{t}$ & & & & & $-1.07 *$ \\
\hline $\mathbf{R}^{2}$ & 0.63 & 0.71 & 0.75 & 0.61 & 0.73 \\
\hline
\end{tabular}

* : significant at $1 \%$ error level, $* *$ : significant at $5 \%$ error level, $* * *$ : significant at $10 \%$ error level

According to the estimation results in Table 1, we found that the following general results are plausible and in line with our expectations. Like most oil-producing countries, fiscal policy is pro-cyclical in Saudi Arabia. A rise in oil prices increases government revenues and boost fiscal spending, which stimulates non-oil activity. The results showed also that increasing non-oil revenue has enhanced government spending that helped, but to a lesser extent, boost total consumption and private investment, and to maintain the role of the government in driving the growth. However, the accelerated rise in non-oil revenue (through implementing VAT and introducing fees and taxes) has affected negatively the private investment and consumption. In fact, the coefficient of the non-oil revenue $\left(\boldsymbol{N O} \boldsymbol{R}_{\boldsymbol{t}}\right)$ is negative and significant in both equations (3) and (4), which means that an increase of revenue away from oil put more pressure on the private sector and started to weaken the consumption. This negative relationship is confirmed by other researches for developed countries, showing that an increase in tax revenues boost Government spending but at the same time could have a significant negative impact on real non-oil GDP growth. 
Despite the purpose and the approach adopted in our paper are different than the IMF Paper $^{2}$ on Saudi Arabia, but the final conclusion is quite similar, highlighting that as long as the government is continuing aggressively with its reforms, by implementing new taxes and fees, the private sector would likely deteriorate and household consumption would also decrease, causing an early fading of expansionary fiscal policy.

\subsection{Scenario Analysis}

Another way to assess the impact of the economic reforms on the fiscal policy adopted recently by the Kingdom of Saudi Arabia is to simulate alternative scenarios about the pace of fiscal reforms going forward and to analyze its implications. For our simulation, we used our model to trace the movements of the endogenous variables under different economic scenarios of non-oil revenue growth. The analysis of these scenarios is one of the goals of this study, which allows us to evaluate the effect of the revenue diversification far from oil, as well as to analyze its implications on the realistic objectives of Vision 2030.

Therefore, we adopted 5 scenarios of non-oil revenue growth. Besides the baseline scenario and the Budget statement 2019 estimations, we assumed that non-oil revenue growth will average 0\%,10\%, and $20 \%$. These five scenarios reflect the potential government approaches in the next 3 years regarding its fiscal reforms (Figure 3).

Figure 3: Non-oil revenue growth scenarios (\%)

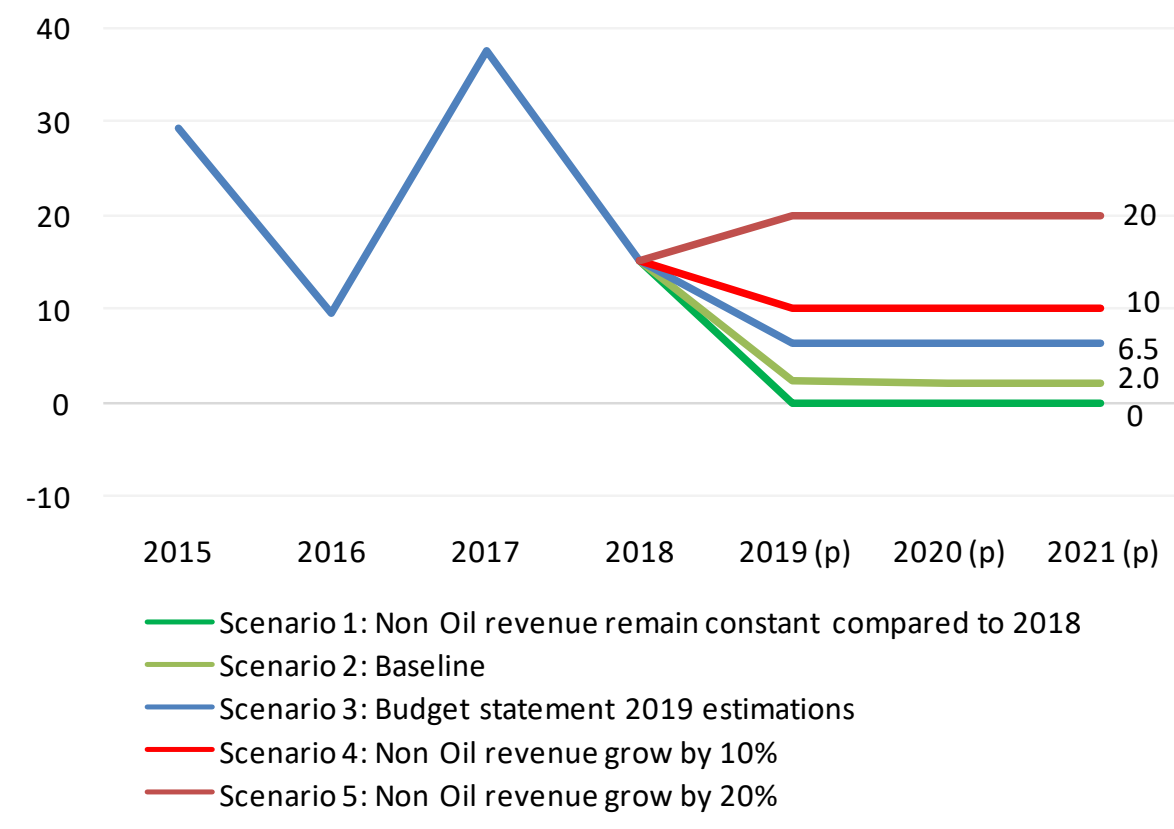

Source: General Authority for Statistics, Author projections

${ }^{2}$ IMF staff team (2019), "Non-oil revenues reforms: an initial assessment of the fiscal and economic impact", IMF Selected Issues Paper. 
The main results indicate that the non-oil revenue fluctuation has a significant impact on some selected variables. Figure 4 and 5 illustrates the effects of non-oil revenue on consumption and private investments growth during the period 2019-2021. According to these scenarios, higher revenues from the private sector will put more pressure on businesses and households (Scenarios 4 and 5), while slowing or even stopping the increase of taxes and fees (Scenarios 1 and 2), could improve gradually consumption and investments, and then stimulate the non-oil economy.

Figure 4: Impact on private investments growth (\%) 20

10

$-10$

$-20$
Figure 5: Impact on consumption growth $(\%)$

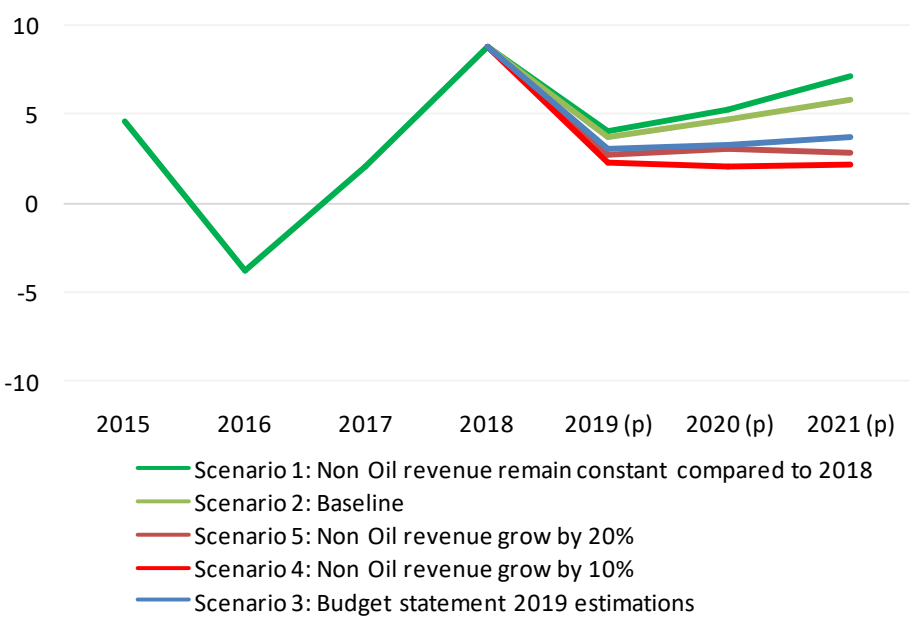

It is important to note here that diversifying revenue sources from oil has a significant role in increasing Government revenue and consequently rising spending to boost economic growth. However, the model results and the scenarios highlighted the negative effects of taxes on the KSA economy, especially in the private sector, despite the increase of government expenditure.

\section{Conclusion and Policy Recommendations}

Saudi Arabia plans to shift its economy from government-driven growth to private sector-led growth. In doing so, the Vision 2030 has been announced and executed, which has many implications in the macroeconomic variables. One of the major elements of the vision is to reduce the dependency of government revenue on oil and increase the non-oil revenue. Such a shift in the source of income from the government would impact the cost of doing business and also private consumption. In this paper, the attempts are to measure the impact on business climate and private consumption. We have found that an increase in non-oil revenue has created pressure on the economy. In the meantime, such a policy that announces the government plan in increasing the non-oil revenue more than five times the base year, which in our case is 2015 . 
The finding in this paper has shown that three channels can affect negatively the growth. The first one is similar to the Ricardian equivalent. But in the case of KSA, the government has announced an increase of taxes and fees to raise revenue more than five times its current base. As expected in the theory, private consumption would decline, and people start to change their consumption behavior in preparing themselves for future taxes and fees announced by the government. In addition, the uncertainty created for private investors has soared to a level that it is negatively impacting private investments. The second source of investor discomfort could come from an increase in the cost of loans resulting from an increase of government debt to finance the budget either through the crowding out private sector or the effect on the country rate as a result of the increase of the cost of servicing government external debt. Additionally, the rise of the cost of doing business in the KSA, given that these reforms have added additional cost to the business. The government has acknowledged such effects, by announcing private sector support. These effects could jeopardize the future role of nonoil export that the vision 2030 depends on it to lead the growth dependence away from oil export.

The results of the model suggest a negative relationship between the growth of the economy and nonoil revenue resulting from the government's new policies. Hence, reducing the size of the government and the budget through the use of Public-Private Partnership (PPP) to reduce the need to increase taxes and fees to raise non-oil revenue would have three positive impacts on private investment and consumption. First, reduce the uncertainty in private sector future taxation. Second, decrease the cost of doing business. Third, reverse the crowding out of the private sector and allow them to be part of the non-oil development not through government contracts but through investment in development projects. Such a switch in government policy actions would restore and perpetuate improved certainty in the private sector and help to stimulate investment and consumption spending domestically. Investment incentives could help accelerate private sector investment in import substitution investments and eventually investments in additional export creating industries. 


\section{References}

Eken, S., T. Helbling, and A. Mazarei (1997), "Fiscal Policy and Growth in the Middle East and North Africa Region”, IMF Working Paper No. 97/101.

Haq-Padda I, and Akram N (2009), "The impact of tax policies on economic growth: Evidence from South-Asian Economies", The Pakistan Development Review.

Ramot Ichihashi M (2012), "The effects of tax structure on economic growth and income inequality". Hiroshima University, Japan.

IMF staff team (2019), "Non-oil revenues reforms: an initial assessment of the fiscal and economic impact”, IMF Selected Issues Paper.

Widmalm F. (2001), "Tax structures and growth: Are some taxes better than others?', Public Choice, 107(3/4):199-219.

Lee Y, Gordon R. (2005), “Tax structure and economic growth”, Journal of Public Economics, 89(56):1027-1043.

Odhiambo and Olushola (2018), "Taxation and Economic Growth in a Resource-RichCountry: The Case of Nigeria”, IntechOpen pp 61-81.

Kaghazian S., Naghdi Y. and Pourshian N. (2013), “The Relationship between Tax Effort and Oil Revenue in Selected Oil Countries”, Middle-East Journal of Scientific Research 15 (4): 493-499.

Padovano F, Galli E. (2001), "Tax rate and economic growth in the OECD countries", Economic Inquiry, 1(39):44-57.

Srithongrung, A.; Sánchez-Juárez, I. (2015), "Fiscal policies and subnational economic growth in Mexico", International Journal of Economics and Financial Issues, N5, 11-22.

Nijkamp, P., and J. Poot (2004), "Meta-Analysis of the Effect of Fiscal Policies on Long-Run Growth”, European Journal of Political Economy, Vol. 20, pp. 91-124.

Al-Yousif, Y. (2000), "Do Government Expenditures Inhibit or Promote Economic Growth: Some Empirical Evidence from Saudi Arabia” The Indian Economic Journal, Vol. 48, pp. 92-96.

Kireyev, (1998), "Key Issues Concerning Non-Oil Sector in Saudi Arabia", Recent Economic Development Issue, Vol. 48, pp. 29-33, International Monetary Fund.

Aschauer, (1989), "Is Public Expenditure Productive?” Journal of Monetary Economics Vol. 23, pp. 177-200.

Ayadi, O. F., A. Chatterjee, and C. P. Obi, (2000), "A Vector Autoregressive (VAR) Analysis of an Oil-Dependent Emerging Economy-Nigeria”, OPEC Review, December, pp. 329-349.

Richards, A., and Waterbury, J. (2007), “A Political Economy of the Middle East”, Third Edition, West view Press, Colorado: Boulder.

IMF reports, 2017-2018: Article IV consultations staff reports for Saudi Arabia

Tim Callen, et al., "Economic Diversification in the GCC: Past, Present, and Future". Staff Discussion Notes 14/12, IMF, Washington. 


\section{Appendices}

Appendix 1, Table A1: Detailed variable definitions and data sources

\begin{tabular}{|c|c|c|c|}
\hline Abbr. & Variable & Units & Data source \\
\hline$B P_{t}$ & Brent price growth & Change, $\%$ & Bloomberg \\
\hline$N O G D P G_{t}$ & Real Non-Oil GDP growth & Change, $\%$ & General Authority for Statistics \\
\hline$P I_{t}$ & Private investment growth & Change, $\%$ & General Authority for Statistics \\
\hline Cons $_{t}$ & Total consumption growth & Change, $\%$ & General Authority for Statistics \\
\hline$F D I_{t}$ & Foreign Direct Investment inflows growth & Change, $\%$ & $\begin{array}{l}\text { General Authority for Statistics / } \\
\text { UNCTAD }\end{array}$ \\
\hline$N P L_{t}$ & Non-Performing Loans growth & Change, $\%$ & SAMA \\
\hline$B D_{t}$ & Total Bank Deposit growth & Change, $\%$ & SAMA \\
\hline$F F R_{t}$ & US Federal Funds Rate & Rate, $\%$ & US Federal Reserve/ Bloomberg \\
\hline$O R_{t}$ & Oil Revenue growth & Change, $\%$ & $\begin{array}{l}\text { SAMA / General Authority for } \\
\text { Statistics }\end{array}$ \\
\hline$O P_{t}$ & Oil production growth & Change, $\%$ & OPEC / Bloomberg \\
\hline $\operatorname{Debt}_{t}$ & Total Government Debt growth & Change, $\%$ & $\begin{array}{l}\text { SAMA / General Authority for } \\
\text { Statistics }\end{array}$ \\
\hline$G S_{t}$ & Government spending growth & Change, $\%$ & $\begin{array}{l}\text { SAMA / General Authority for } \\
\text { Statistics }\end{array}$ \\
\hline$E P I_{t}$ & Economic Partners Index growth & Change, $\%$ & IMF / Authors' calculation \\
\hline$D C_{t}$ & Domestic credit growth & Change, $\%$ & SAMA \\
\hline
\end{tabular}




\section{Appendix 2: Model Estimation Quality}

The predictive power of the model is one of the important criteria for choosing this approach. Thus, in order to test the performance of our model, we estimated our five equations over the period 19902015 and then we predicted our outputs for the period 2016-2018, which means that we have 3 periods for forecasting. For this evaluation, the actual realizations for the exogenous variables in the models are used instead of assumptions.

We start our analysis by estimating the six equations using simple OLS regressions. In fact, in order to take into consideration all different channels through which main macroeconomic drivers can affect the Saudi economic activity, this model is solved simultaneously, allowing for interactions among the variables, instead of solving it sequentially by blocks. The results are generally satisfactory and in line with economic theory.

Concerning the predictive performance of the model, there are many ways to measure forecast accuracy. We choose in this paper two of the most common methods, given the characteristic of our model. The first method is to calculate the Theil U-statistics ${ }^{3}$, over the period 2016 to 2018.

$$
U=\frac{\sqrt{\frac{1}{T} \sum_{t=1}^{T}\left(Y_{t}^{s}-Y_{t}^{a}\right)^{2}}}{\sqrt{\sum_{t=1}^{T}\left(Y_{t}^{S}\right)^{2}}+\sqrt{\sum_{t=1}^{T}\left(Y_{t}^{a}\right)^{2}}}
$$

Where $\mathrm{Y}^{\mathrm{s}}$ is the out-of-sample simulation for variable $\mathrm{Y}, \mathrm{Y}^{\mathrm{a}}$ is the actual historical value for $\mathrm{Y}$, and $\mathrm{T}$ is the total number of forecasts for $Y$. Given that it covers a finite range, the $U$ statistic is easier to interpret than other accuracy gauges such as the root mean squared error (RMSE) or the Mean Absolute Error (MAE). In fact, a Theil U greater than 1 is undesirable and the closer the statistic is to 0 the more robust the predictive accuracy. In general, a Theil $U$ less than or equal to 0.55 is deemed adequate. Table A2 gives the results for the five equations and indicates that the model mimics the behavior of the main macroeconomic variables in the Saudi economy fairly well.

Table A2: Model Predictive Accuracy for the period 2016-2018

\begin{tabular}{|c|c|c|c|c|c|}
\cline { 2 - 6 } & Equation (1) & Equation (2) & Equation (3) & Equation (4) & Equation (5) \\
\hline U-Statistic & 0.11 & 0.09 & 0.07 & 0.10 & 0.08 \\
\hline \hline
\end{tabular}

\footnotetext{
${ }^{3}$ Theil, H. (1958), “Economic Forecasts and Policy”. Amsterdam: North Holland.
} 
The second method to test the performance of the model is to compare the actual and fitted values during the whole period of the study (1990-2015). Figure A1 showed the estimations of the equation 1 related to the real non-oil GDP growth, compared to their historical values, which indicates that the model picks up the major turning points in the series reasonably well.

\section{Figure A1: Real non-oil GDP growth (\%): Actual vs Fitted}

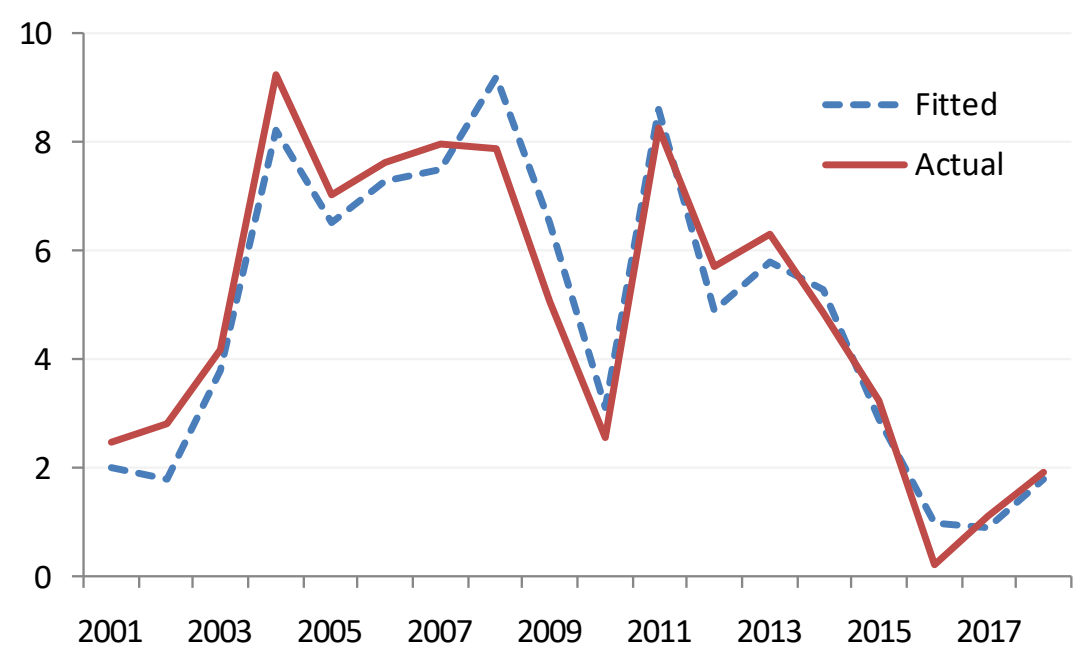

Source: General Authority for Statistics, Author estimations 


\section{Appendix 3: Baseline forecast results}

Given the performance of our model and the plausibility of its results, we used our five equations to estimate our baseline forecasts for the period 2019-2021. In general, forecasting models require assumptions regarding future fluctuations of the exogenous variables, which are often numerous and difficult to predict. However, in our adopted model, all data used are endogenous, except for the Saudi oil production, Brent price, FFR and the Economic Partners Index. Therefore, it is enough to take the projections of these four variables for the period 2019-2021, in order to find all required forecasts related to the five equations. Thus, the most important assumptions in our model concern the Oil production. The KSA oil production is sourced from the OPEC, while the Brent price projections are taken from the IMF World Economic Outlook (WEO) July 2019, which is derived from Brent crude oil future prices. However, it should be noted that oil futures change daily and can be dramatically influenced by a shock or special events (US-China trade war, OPEC agreement, etc.), that will affect the oil price projections.

For the FFR, the assumptions are based on the Federal Funds Rate futures for the United States, available on Bloomberg, while the projection of the EPI is calculated using the GDP projections of the KSA economic partners, sourced from the responsible institutions of each country. Based on these assumptions, Figure A2 showed the real non-oil GDP growth projection from 2019 to 2021, which indicates that the non-oil economic growth would reach $2.9 \%$ in 2021.

\section{Figure A2: Baseline forecast of the Real non-oil GDP growth (\%)}

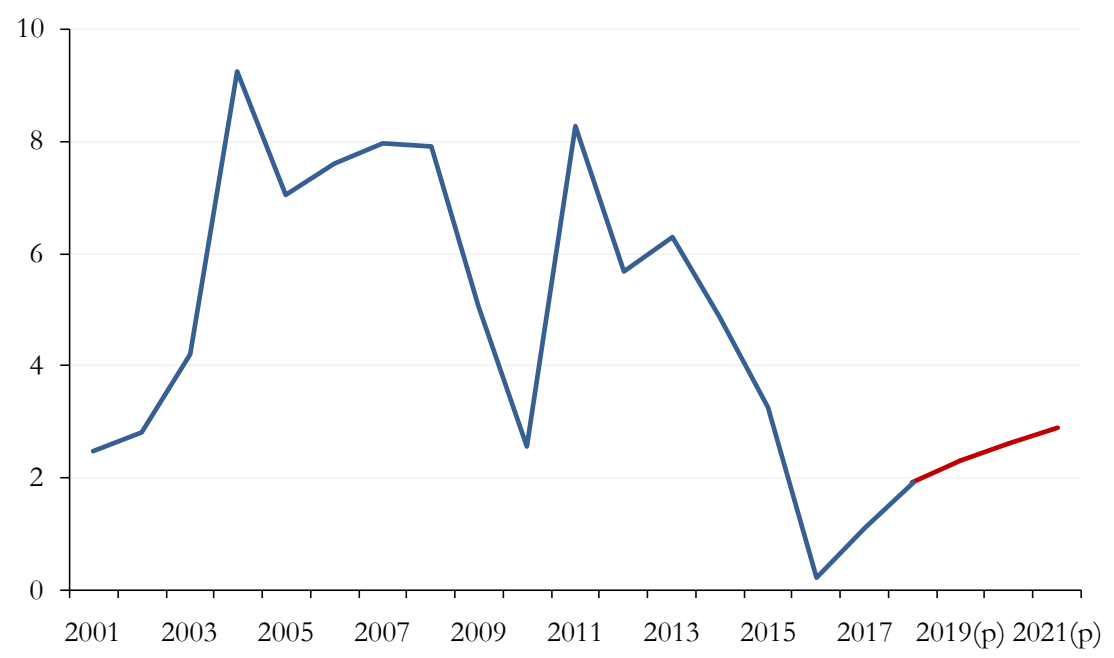

Source: General Authority for Statistics, Author estimations 
Figures

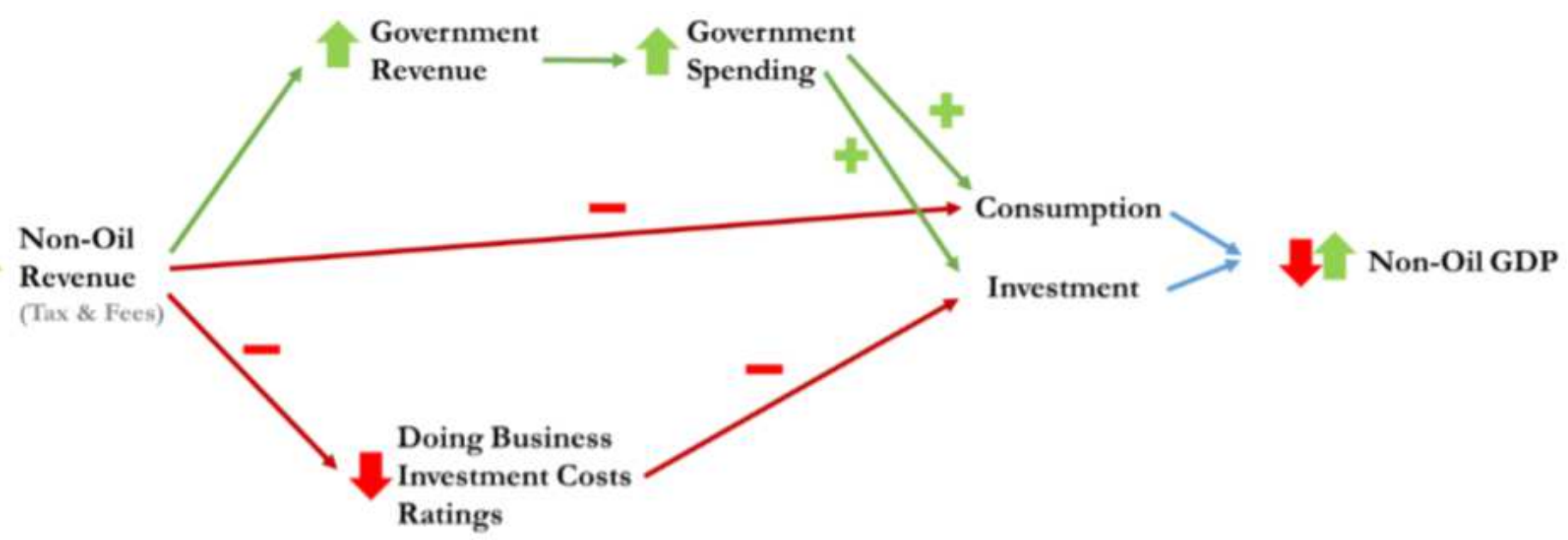

\section{Figure 1}

Mixed effect of increasing non-oil revenue

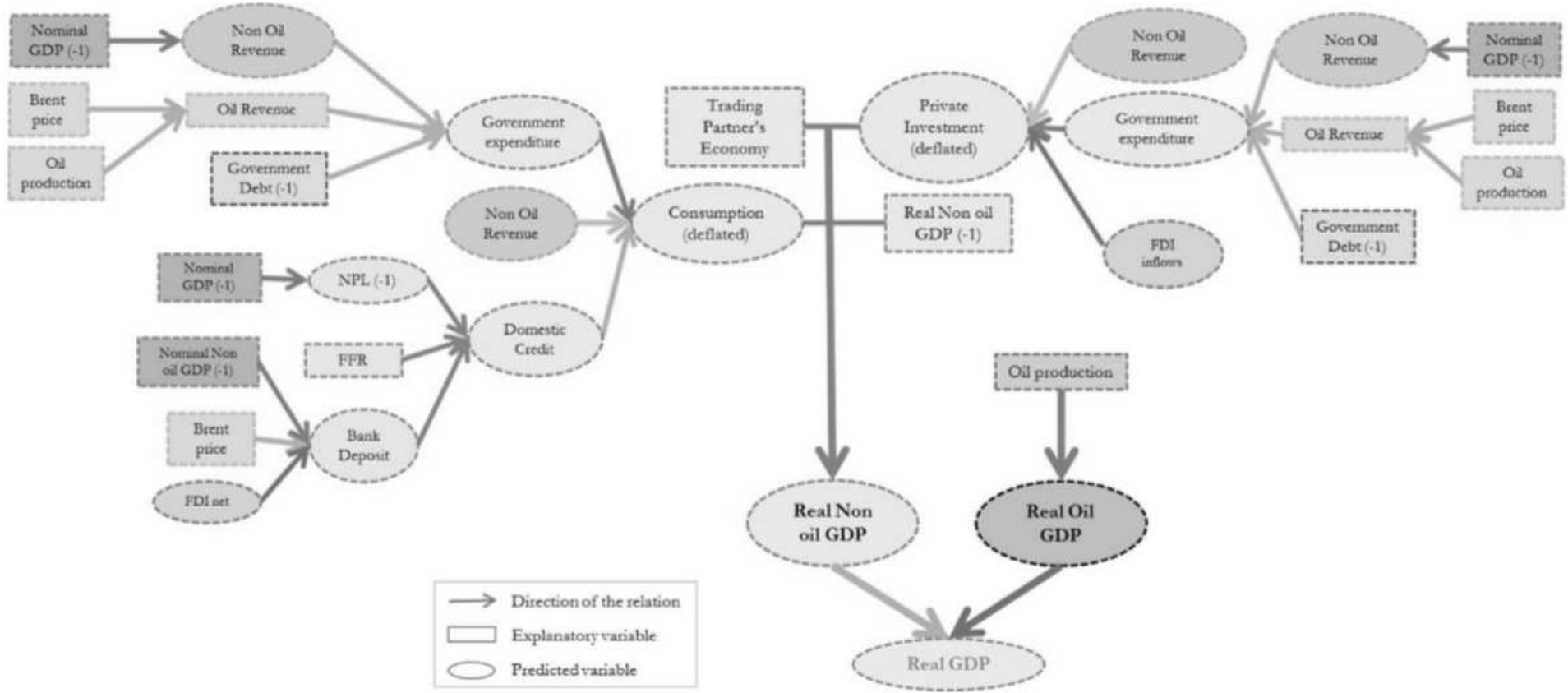

Figure 2

Economic Relationships of the adopted Model 
40

30

20

10

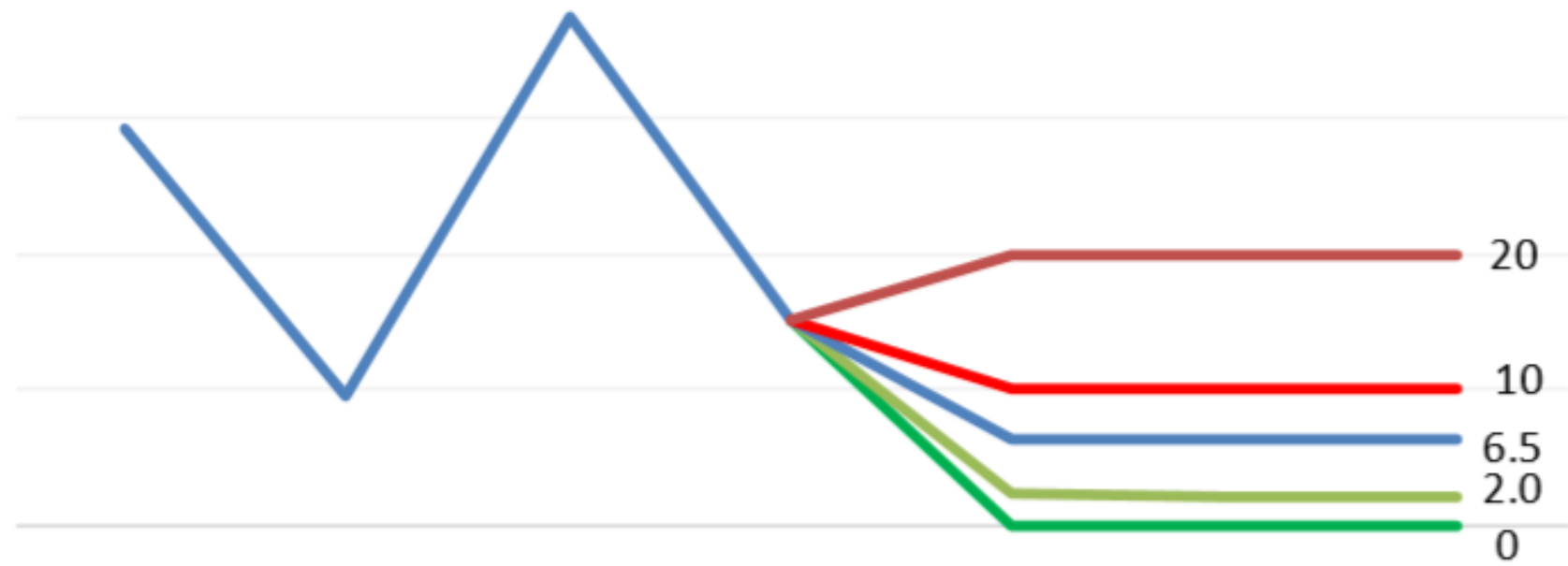

$-10$

$$
20152016 \quad 2017 \quad 2018 \quad 2019(p) \quad 2020(p) \quad 2021(p)
$$

- Scenario 1: Non Oil revenue remain constant compared to 2018

- Scenario 2: Baseline

— Scenario 3: Budget statement 2019 estimations

- Scenario 4: Non Oil revenue grow by $10 \%$

- Scenario 5: Non Oil revenue grow by $20 \%$

\section{Figure 3}

Non-oil revenue growth scenarios (\%) Source: General Authority for Statistics, Author projections 
10

0

$-10$

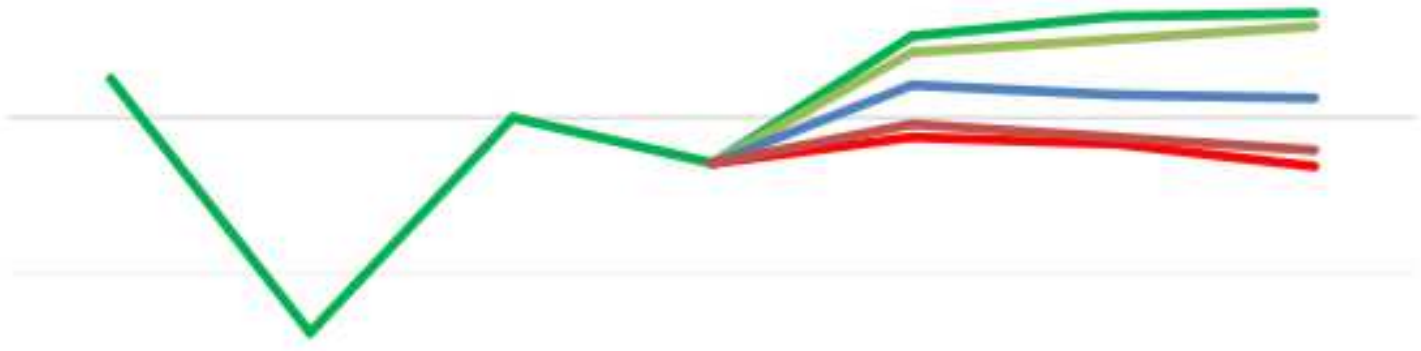

$-20$

$$
\begin{array}{lllllll}
2015 & 2016 & 2017 & 2018 & 2019(p) & 2020(p) & 2021(p)
\end{array}
$$

- Scenario 1: Non Oil revenue remain constant compared to 2018

- Scenario 2: Baseline

- Scenario 3: Budget statement 2019 estimations

- Scenario 4: Non Oil revenue grow by $10 \%$

- Scenario 5 : Non Oil revenue grow by $20 \%$

\section{Figure 4}

Impact on private investments growth (\%)

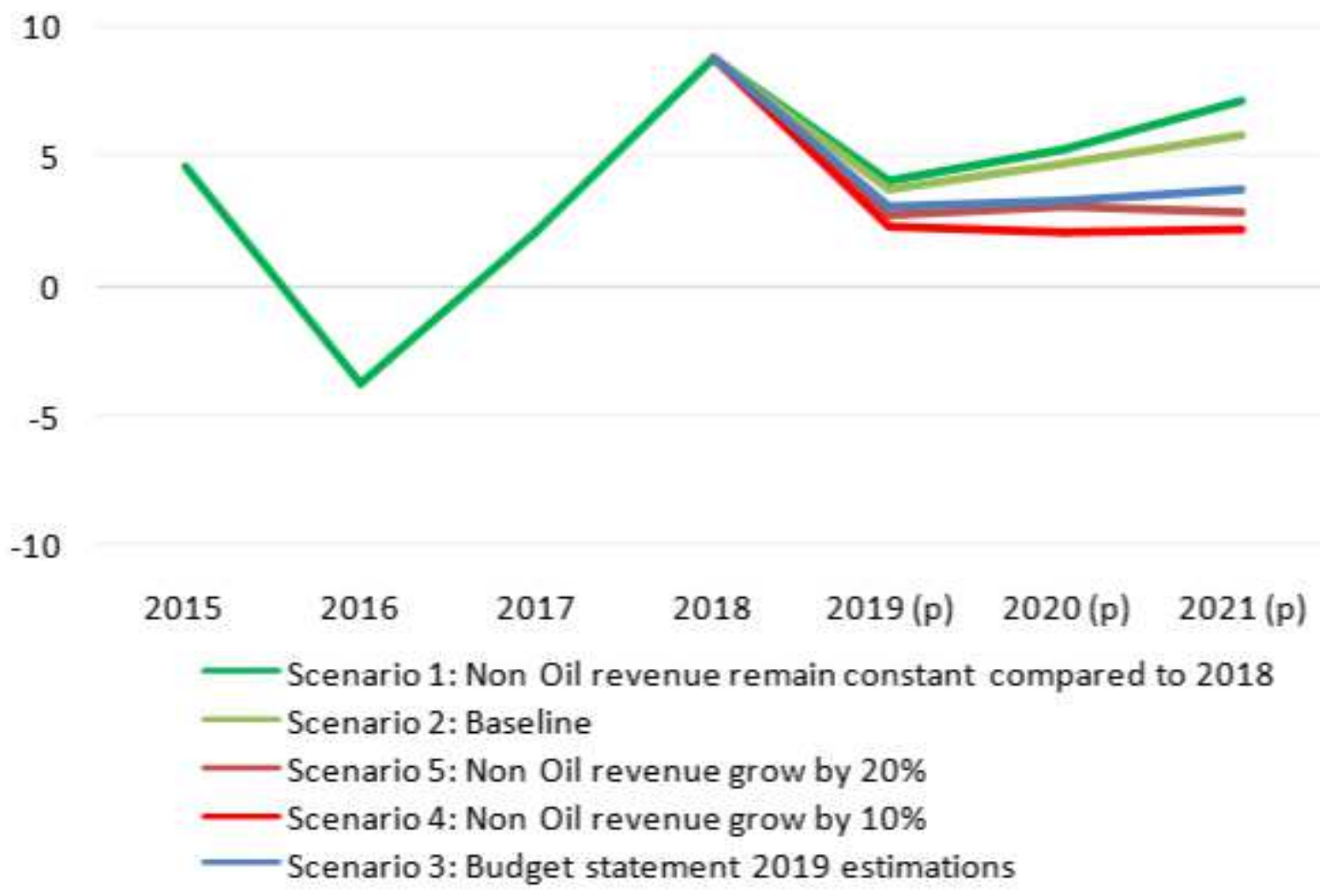


Figure 5

Impact on consumption growth (\%) 